\title{
Techniques for the Quantitative Analysis of Fission Product Noble Metals
}
A. W. Lautensleger
F. T. Hara

August 1982

Prepared for the U.S. Department of Energy under Contract DE-AC06-76RLO 1830

Pacific Northwest Laboratory Operated for the U.S. Department of Energy by Battelle Memorial Institute 


\title{
DISCLAIMER
}

This report was prepared as an account of work sponsored by an agency of the United States Government. Neither the United States Government nor any agency thereof, nor any of their employees, makes any warranty, express or implied, or assumes any legal liability or responsibility for the accuracy, completeness, or usefulness of any information, apparatus, product, or process disclosed, or represents that its use would not infringe privately owned rights. Reference herein to any specific commercial product, process, or service by trade name, trademark, manufacturer, or otherwise, does not necessarily constitute or imply its endorsement, recommendation, or favoring by the United States Government or any agency thereof. The views and opinions of authors expressed herein do not necessarily state or reflect those of the United States Government or any agency thereof.

\author{
PACIFIC NORTHWEST LABORATORY \\ operated by \\ BATTELLE \\ for the \\ UNITED STATES DEPARTMENT OF ENERGY \\ under Contract DE-AC06-76RLO 1830
}

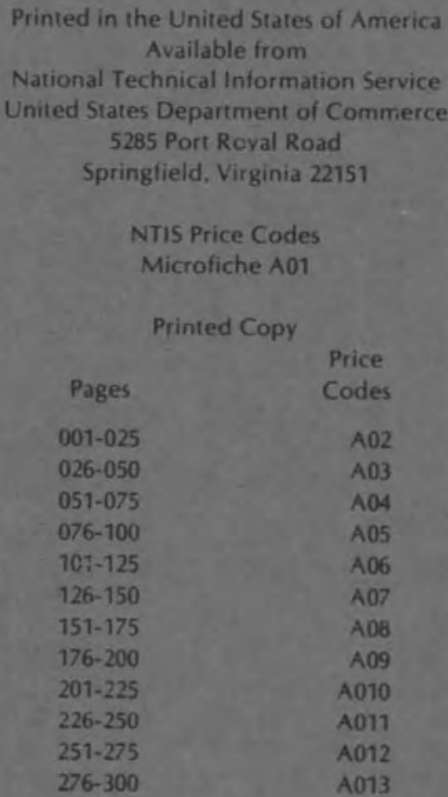


A. W. Lautensleger

F. T. Hara

August 1982

Prepared for the U.S. Department of Energy under Contract DE-ACO6-76RLO 1830 


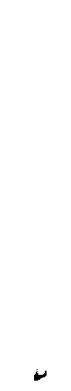


Analytical procedures for the determination of ruthenium, rhodium, and palladium in precursor waste, solvent metal, and final glass waste forms have been developed. Two procedures for the analysis of noble metals in the calcine and glass waste forms are described in this report. The first is a fast and simple technique that combines inductively coupled argon plasma atomic emission spectrometry (ICP) and X-ray fluorescence techniques and can only be used on nonradioactive materials. The second procedure is based on a noble metal separation step, followed by an analysis using ICP. This second method is more complicated than the first, but it will work on radioactive materials.

Also described is a procedure for the ICP analysis of noble metals in the "solvent metal" matrix. The only "solvent metal" addressed in this procedure is lead, but with minor changes the procedure could be applied to any of the solvent metals being considered in the Pacific Northwest Laboratory (PNL) extraction process. A brief explanation of atomic spectroscopy and the ICP analytical process, as well as of certain aspects of ICP performance (interelement spectral line interferences and certain matrix effects) is given. 


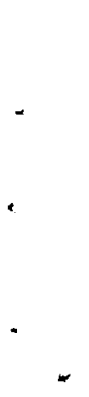

,

$\cdot$

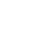




\section{CONTENTS}

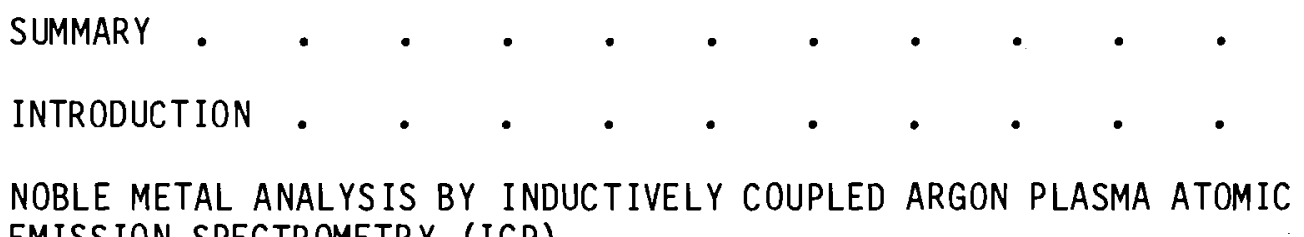

EMISSION SPECTROMETRY (ICP)

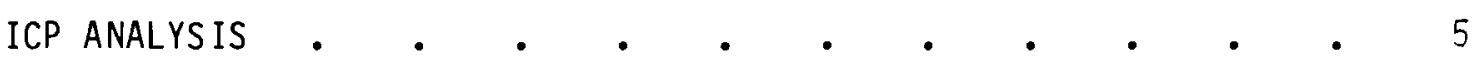

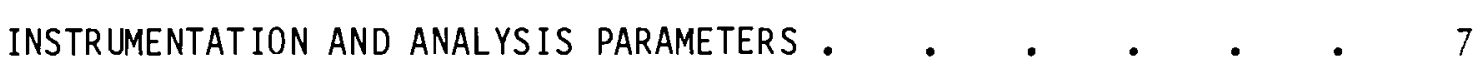

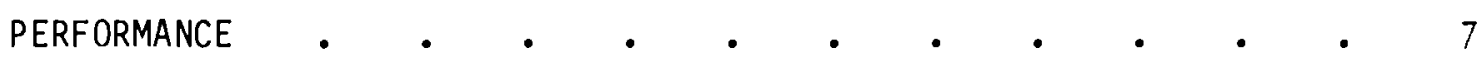

Interelement Spectral Line Interferences $\quad$. $\quad . \quad$ - 8

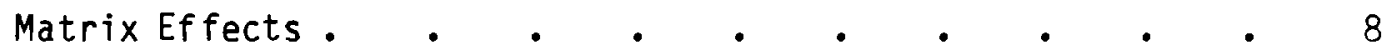

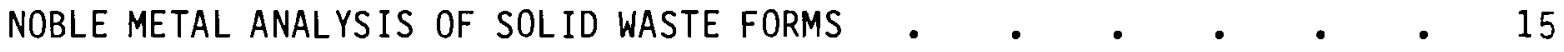

NOBLE METAL ANALYSIS OF NONRADIOACTIVE CALCINE AND GLASS • • 15

NOBLE METAL ANALYSIS OF FISSION PRODUCT CALCINE AND GLASS • • 18

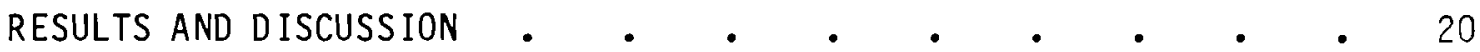

NOBLE METAL ANALYS IS OF THE "SOLVENT METAL" •

ANALYS IS OF NOBLE METALS IN THE LEAD SOLVENT METAL BUTTON $\quad$ • 28

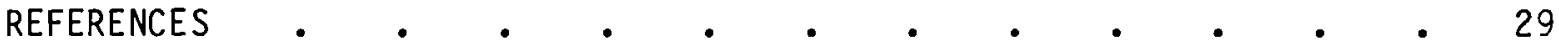

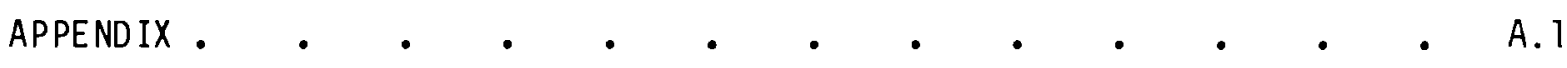


FIGURES

1 Schematic Diagram of an ICP Spectrometer System $\quad$. $\quad$ • $\quad$ • $\quad$ e 6

2 ICP Determination of Rh in Three Matrices . . . . $\quad 12$

3 ICP Determination of Pd in Three Matrices . $\quad . \quad$ e $\quad . \quad 13$

4 ICP Determination of Ru in Three Matrices . . . . . $\quad$. 14

$5 X$-Ray Spectrum of the PW-4b-7 Calcine in the 14 to $25 \mathrm{KeV}$ Energy Region . . . . . . . . . . 17

6 PW-4b-7 Calcine X-Ray Spectrum with the MoK $\alpha$ and $K_{B}$ Peaks Removed 18

7 Schematic Representation of the Analysis of Noble Metals

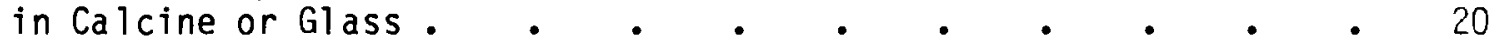

8 Microstructure of Bismuth "Solvent Metal" Button . . . . . 24

9 Microstructure of Bi smuth "Solvent Metal" Button . . . . $\quad$ • 25

10 Microstructure of Lead "Solvent Metal" Button . • . . 26

11 Microstructure of Lead "Solvent Metal" Button _ . $\quad$ • . 27

\section{TABLES}

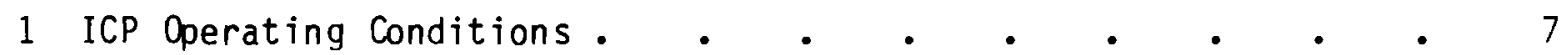

2 Percent Interference Values for $\mathrm{Ru}(240.3 \mathrm{~nm}), \mathrm{Rh}(343.5 \mathrm{~nm})$, and

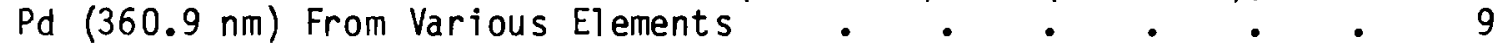

3 The Effects of $\mathrm{Zn}-\mathrm{Na}$ and $\mathrm{Pb}$ Matrices on the ICP Determination of $\mathrm{Ru}, \mathrm{Rh}$, and $\mathrm{Pd}$. $\quad . \quad . \quad . \quad . \quad . \quad . \quad . \quad . \quad$.

4 ICP Analysis of the Calcine PW-4b-7 $\quad$ e $\quad . \quad . \quad . \quad . \quad . \quad 16$

5 Noble Metal Analysis of the PW-4b-7 Calcine Using the Reduction Procedure.

6 Noble Metal Spike Recoveries . . . . . . . . . 


\section{INTRODUCTION}

In 1979 and 1980 the Pacific Northwest Laboratory (PNL), operated by Battelle Memorial Institute for DOE, conducted a study that evaluated the technical and economic factors influencing the recovery and use of the noble metals, palladium, ( $P d)$, rhodium ( $R h)$, and ruthenium ( $R u$ ) (produced by the fission of uranium and plutonim in nuclear reactors) (Jensen 1980). This study led to the funding of an on-going research program to develop a cost effective, waste management-compatible process for extracting noble metals from defense, and possibly commercial, fission product waste. In the PNL process under study, lead oxide, or another suitable metal oxide, is mixed with the fission products containing the noble metals, a reducing agent such as charcoal or flour, and glass forming materials. The mixture is fused and the metal oxide is reduced to the molten meta 1. During this reducing process, the molten metal separates the noble metals from the waste, thus forming an ingot containing relatively pure noble metals.

The objective of this report is to identify quantitative analytical procedures for examining fission product noble metals in the precursor waste, the solvent metal, and the final glass-waste form.

The report has three main sections: 1) application of ICP to noble metal analysis, 2) the noble metal analysis of solid fission product waste forms, and 3 ) the noble metal analysis of the "solvent metal" button.

The first section gives a brief description of basic ICP principles and then evaluates the performance of the ICP as it is applied to the analysis of the noble metals. Areas of performance that are addressed for the ICP emission lines Ru $240.3 \mathrm{~nm}$, Rh $343.5 \mathrm{~nm}$, and $\mathrm{Pd} 360.9 \mathrm{~nm}$ consist of interelemental spectral interferences and certain matrix effects. In general, the spectral interferences for these noble metal lines from the other elements tested are minor. These minor spectral interferences can be realiably corrected for.

In the section on noble metal analysis of solid waste forms, two procedures are described. In an ideal situation the ICP noble metal analysis of a solid material would be obtained by converting the solid into a liquid form by 
a $\mathrm{Na}_{2} \mathrm{O}_{2} / \mathrm{NaOH}$ fusion and then performing the subsequent ICP analysis directly on this liquid. During the initial part of this work a fast and accurate noble metal analytical procedure was needed to support the ongoing fission product noble metal extraction optimization research. At this time the ICP being used had only the ability to analyze for Ru directly from the fused calcine. A scanning monochromator was available to look at some of the lines of $\mathrm{Pd}$ and $\mathrm{Rh}$, but because of poor resolving power and a few spectral interferences, this proved to be inaequate. Under these circumstances, the first procedure in this section, which uses a combination of ICP and $x$-ray fluorescence spectrometry, was developed. This ICP/x-ray fluorescence procedure worked quite well, meeting of the initial analytical needs of the nonradioactive noble metal extraction optimization research.

Because of an inability of the $x$-ray units solid state detector to handle highly radioactive materials, another approach was needed for the noble metal analysis of the actual fission material. First, the addition of both Rh and Pd channels to the direct reading polychromator was tried, in hopes that the higher resolving power would decrease the size and numbers of the spectral interferences. This worked for the $\mathrm{Rh} 343.5 \mathrm{~nm}$ line, making it possible to analyze for Rh directly from the fused calcine, but a problem remained with the $\mathrm{Pd}$ 360.9-nm line. Further investigation revealed an extremely strong $(170 \%)$, previously undetected Samarium (Sm) interference. As interferences of this size cannot be reliably corrected for, the alternatives at this point were to either search for another line of emission or separate the Pd from the interfering Sm. Instrumental commitment to the Pd 360.9-nm line, as well as the fact that such a separation would remove most of the highly radioactive components (leaving a sample that would be much safer and easier to handle) led to the development of a $Z n$ reduction separation procedure. This procedure is more complicated and time consuming than the ICP/x-ray fluorescence technique but will work on either radioactive or nonradioactive materials.

With some further time and effort, a Pd line that does not have these severe interference problems could possibly be found. If this were the case, and the radioactivity of the sample that was to be analyzed was of little importance, then an ICP analysis for all three noble metals could be carried 
out directly on the fused solid material. This would save considerable time and money in costly hot cell sample preparations.

The final section of this report discusses the analysis of the "solvent metal" matrices. When the noble metal extraction research began, several metals ( $\mathrm{Pb}, \mathrm{Bi}, \mathrm{Sb}, \mathrm{Sn}$, and $\mathrm{Cu}$ ) were considered as possible "solvent metals". As the research progressed it became apparent that $\mathrm{Pb}$ was probably going to be the metal of choice so the only analysis procedure given is that for the Pb matrix. The analytical schemes for the other solvent metals are basically the same with the only differences being the amounts and types of acids used in the sample dissolution step.

Al so included in this section are the results of a scanning electron microscope and an electron microprobe analysis of the $\mathrm{Pb}$ and $\mathrm{Bi}$ "solvent metal" matrices. The results of these analyses showed that the "solvent metal" matrices are not homogeneous in composition with respect to the noble metals. With small sample sizes such as those generated in the lab scale process, this does not represent a problem because the whole button can be digested. As the process is increased in size to pilot and production scales, the size of the button being produced also increases. As this happens, the difficulty of obtaining a representative sample could increase, making it more difficult to obtain a reliable analysis. 


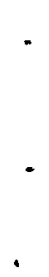


NOBLE METAL ANALYSIS BY INDUCT IVELY COUPLED

ARGON PLASMA EMISSION ATOMIC SPECTROMETRY (ICP)

The most useful methods for noble metal analysis are those that allow for the determination of a single noble metal in the presence of others, as well as for the simultaneous determination of all the noble metals from the same sample. Because chemical properties of noble metals, and the subsequent reactions they undergo are similar, most traditional methods of analysis such as colorimetric and gravimetric techniques will not meet these criteria. However, analysis based on atomic spectroscopy will.

Atomic spectroscopy deals with the direct absorption and emission of light by atoms, with each element having its own characteristic spectrum. In emission spectroscopy, the spectrum of light emitted by an excited sample is characteristic of the elements in that sample, and the intensities of the spectral lines associated with the individual elements are proportional to their concentrations.

Spectroscopic methods such as $x$-ray fluorescence and Atomic Absorption Spectrometry (Cruickshank and Munro 1979; Oumo and Nieboer 1979; Sandoz 1966; Scharborough 1969) have been used to determine noble metals in a variety of matrices. We chose to study the application of inductively coupled argon plasma (ICP) atomic emission spectrometry to noble metal analysis. Because there are several excellent review papers available on ICP (Fassel 1979; Fassel 1978; Hanson and Ediger 1980), only a simple explanation of the overall ICP system, and how it works in the analysis of a sample will be given. ICP ANALYSIS

Figure 1 shows a schematic layout of the overall ICP system. The analytical process begins with the introduction of a liquid sample into the plasma source. A peristaltic pump delivers the liquid sample to a crossflow nebulizer (other types of nebulizers are available) where it combines with the water-saturated sample, argon gas flow and forms an aerosol that passes into the expansion chamber. The water saturation of the argon helps keep the nebulizer from plugging during the aspiration of samples containing high salt 


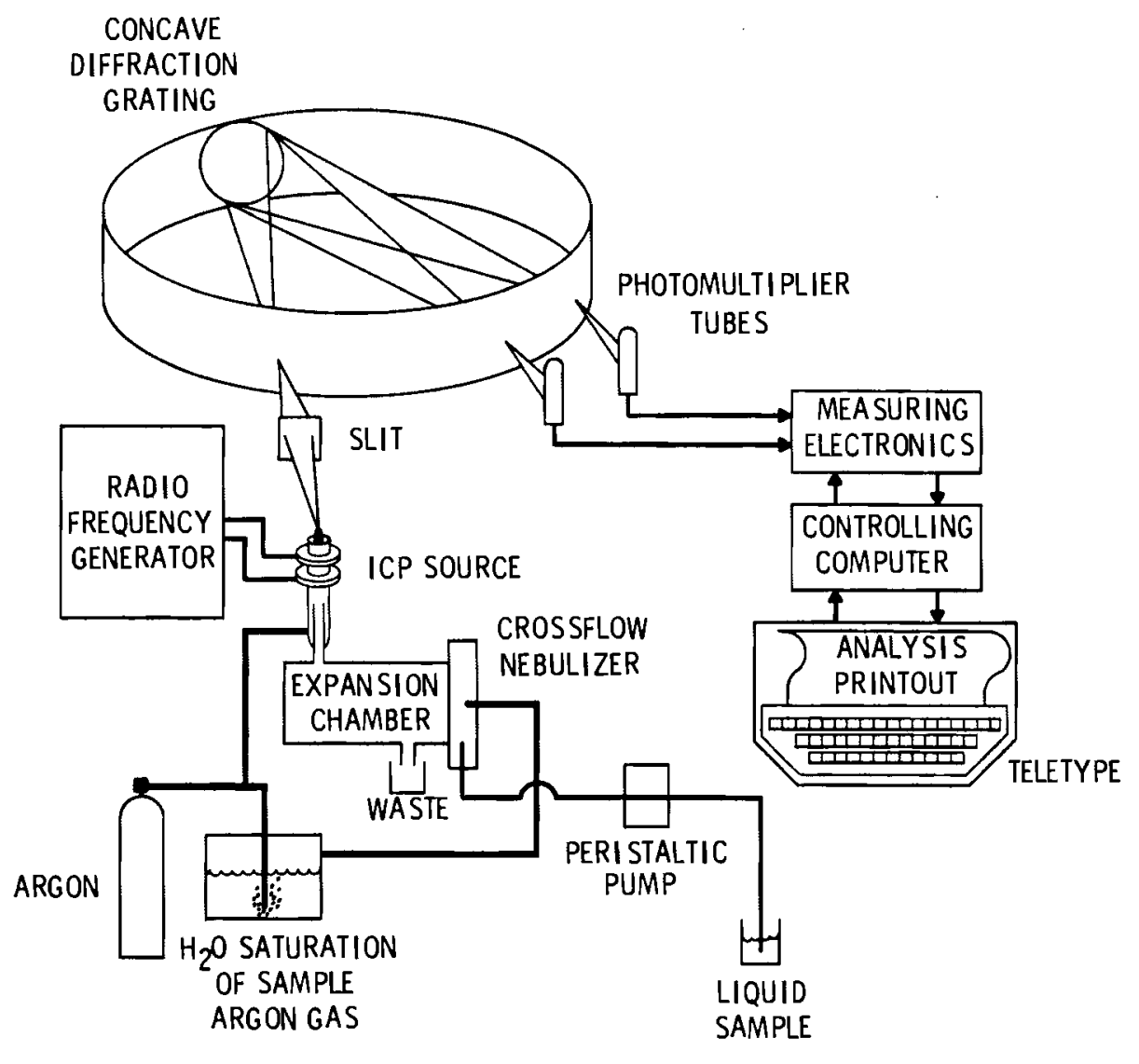

FIGURE 1. Schematic Diagram of an ICP Spectrometer System

levels. In the expansion chamber the larger aerosol droplets condense and drain as waste, and the finer aerosol is carried up into the plasma where desolvation, atomization, and finally excitation occur. The characteristic spectral lines emitted from the elements in the sample pass into the directreading spectrometer through an entrance slit, and are reflected off a concave diffraction grating. Different wavelengths of light are reflected at different angles, so pre-aligned photomultiplier tubes, each representing a certain element, can measure the intensities. This information is fed to the controlling computer where it is translated into the concentrations of the specific elements and then printed out on the teletype. 
INSTRUMENTATION AND ANALYSIS PARAMETERS

A 975 ICP ATOMCOMP® Spectrometer equipped with a $0.5 \mathrm{~m}$ Ebert scanning monochromator was used for the analysis of $\mathrm{Ru}, \mathrm{Ph}$, and $\mathrm{Pd}$. Initially, the analysis of Ru was obtained using the direct-reading spectrometer at a wavelength of $240.27 \mathrm{~nm}$ whereas the Rh and Pd analyses were obtained using the scanning monochromator at wavelengths of $343.49 \mathrm{~nm}$ and $360.95 \mathrm{~nm}$, respectively. Toward the completion of this study Rh and Pd channels (same wavelengths) were added to the direct-reading spectrometer and the scanning monochromator was no longer needed.

The operating conditions for the ICP are shown in Table 1. All three noble metals were calibrated at concentrations of 0.0 and $10.0 \mu \mathrm{g} / \mathrm{mL}$. The $0.0 \mu \mathrm{g} / \mathrm{mL}$ standard was a $2 \% \mathrm{HCl}$ solution made from ULTREX $\odot \mathrm{HCl}$ and deionized water. The $10 \mu \mathrm{g} / \mathrm{mL}$ standards were also $2 \%$ in $\mathrm{HCl}$ and were made from high purity $1000 \mu \mathrm{g} / \mathrm{mL}$ Spex Industries ICP standards.

PERFORMANCE

Areas of ICP performance that were addressed consist of interelement spectral line interferences and certain matrix effects. Because the analysis of $\mathrm{Pd}$ and $\mathrm{Rh}$ was studied on both the scanning monochromator and the directreading polychromator, a comparison of the results will be given when appropriate.

\section{TABLE 1. ICP Operating Conditions}

$\begin{array}{ll}\text { Forward Power at Generator } & 1200 \mathrm{~W} \\ \text { Coolant Argon Fl ow } & 20 \mathrm{~L} / \mathrm{min} \\ \text { Plasma Argon Flow } & 0 \mathrm{~L} / \mathrm{min} \\ \text { Sample Argon Fl ow } & 0.75 \mathrm{~L} / \mathrm{min} \\ \text { Solution Uptake } & 1 \mathrm{~mL} / \mathrm{min}\end{array}$

(बATOMCOMP is a registered trademark of Jarrell-Ash of Waltham, Massachusetts. बULTRX is a registered trademark of J. T Baker Chemical Co. of Phillipsburg, New Jersey. 
Interelement Spectral Line Interferences

Interelement spectral line interferences are common in all forms of emission spectrometry including ICP. Because every element has several lines of emission, most of the major line interferences can be eliminated by careful selection of the analysis lines. The weaker interferences, however, usually cannot be totally avoided, so correction schemes based on measurements of the concentrations of the interfering elements must be used. The ICP being used must have the ability to analyze for the interfering element. Thus, it can assess the degree of the interference from that element from sample to sample.

Table 2 shows most of the interferences for Ru $(240.3 \mathrm{~nm})$, Rh $(343.5 \mathrm{~nm})$, and $\mathrm{Pd}(360.9 \mathrm{~nm})$. Interference values for the $\mathrm{Pd}$ and $\mathrm{Rh} \mathrm{l}$ ines are given for both the scanning monochromator and the direct reading polychromator. These values were obtained by aspirating high purity $100 \mathrm{ppm}$ standards for each of the elements shown and observing the concentration readings of the noble metals.

Table 2 shows that in almost all cases the interferences are larger when the $0.5 \mathrm{~m}$ monochromator is used instead of the $0.75 \mathrm{~m}$ polychromator. This is mainly due to the higher resolving power of the polychromator. Another advantage the direct reader has over the scanning monochromator is that the values of the interferences are more constant with the former. With the monochromator, the interferences will change slightly as it is dialed to different wavelengths because dialing to exactly the same point every time is extremely difficult. Therefore, the important interferences must be re-evaluated each time the monochromator is moved. This is not a problem with the polychromator because all of the individual photomultiplier tubes are placed at fixed wavelengths. Thus, the interferences are relatively constant and can be entered into the controlling computer, which then automatically subtracts them from the appropriate elements each time an analysis is made.

Matrix Effects

In the analysis of noble metals, as it has been described in this report, there are two basic matrices to be considered. The first is associated with the $\mathrm{Zn}$ reduction- $\mathrm{Na}_{2} \mathrm{O}_{2} / \mathrm{NaOH}$ fusion separation procedure, in which the 
TABLE 2. Percent Interference Values for $R u(240.3 \mathrm{~nm})$, Rh $(343.5 \mathrm{~nm})$, Pd $(360.9 \mathrm{~nm})$ From Various Elements

\begin{tabular}{|c|c|c|c|c|c|}
\hline \multirow[b]{2}{*}{ Element } & \multirow{2}{*}{$\begin{array}{c}\text { Ru\% } \\
\text { Interferences } \\
\text { Polychromator } \\
\end{array}$} & \multicolumn{2}{|c|}{ Rh\% Interferences } & \multicolumn{2}{|c|}{ Pd\% Interferences } \\
\hline & & Polychromator & Monochromator & Polychromator & Monochromator \\
\hline \multicolumn{6}{|l|}{$A 1$} \\
\hline B & & & 0.04 & & \\
\hline \multicolumn{6}{|l|}{$\mathrm{Ba}$} \\
\hline \multicolumn{6}{|l|}{$\mathrm{Ca}$} \\
\hline $\mathrm{Ce}$ & 0.05 & 0.05 & 0.48 & 10 & 17 \\
\hline Co & 0.31 & 0.02 & 0.08 & 0.06 & 0.07 \\
\hline $\mathrm{Cr}$ & 0.03 & & & 0.28 & 0.22 \\
\hline Dy & 0.09 & 0.70 & 8.8 & 1.8 & 3.7 \\
\hline Eu & & 0.80 & 4.8 & 0.44 & 0.56 \\
\hline $\mathrm{Fe}$ & 1.4 & & & 0.28 & 1.1 \\
\hline $\mathrm{Gd}$ & 0.01 & 0.14 & 0.30 & 0.49 & 3.0 \\
\hline \multicolumn{6}{|l|}{$k$} \\
\hline $\mathrm{La}$ & & & & 0.08 & 0.47 \\
\hline \multicolumn{6}{|l|}{$\mathrm{Li}$} \\
\hline \multicolumn{6}{|l|}{$\mathrm{Mg}$} \\
\hline \multicolumn{6}{|l|}{ Mn } \\
\hline Mo & 0.03 & 0.87 & 1.4 & 0.10 & 0.08 \\
\hline \multicolumn{6}{|l|}{$\mathrm{Na}$} \\
\hline Nd & 0.04 & 0.35 & 1.4 & 3.3 & 13 \\
\hline $\mathrm{Ni}$ & 0.02 & & & 0.10 & 0.75 \\
\hline \multicolumn{6}{|l|}{$P$} \\
\hline \multicolumn{6}{|l|}{$\mathrm{Pb}$} \\
\hline $\mathrm{Pd}$ & 0.01 & & & & \\
\hline $\mathrm{Rh}$ & .0 .02 & & & 0.10 & 0.16 \\
\hline Ru & & 0.04 & 0.25 & & \\
\hline Si & 0.02 & & & & \\
\hline \multicolumn{6}{|l|}{$T i$} \\
\hline \multicolumn{6}{|l|}{$\mathrm{Zm}$} \\
\hline \multicolumn{6}{|l|}{$T i$} \\
\hline \multicolumn{6}{|l|}{$\mathrm{Zn}$} \\
\hline $\mathrm{Zr}$ & 0.04 & 0.21 & 0.26 & 0.85 & 0.22 \\
\hline
\end{tabular}

(a) Interference values not shown are less than $.01 \%$. 
concentration of $\mathrm{Zn}$ and $\mathrm{Na}$ in the final solution is approximately $800 \mu \mathrm{q} / \mathrm{mL}$ for both. The second matrix deals with the noble metal analysis of the solvent metal buttons in which the final concentration of the solvent metal is approximately $1000 \mu \mathrm{g} / \mathrm{mL}$. For this work we chose to look at lead as the solvent metal matrix.

Table 3 shows the results of the direct-reading polychromator ICP analysis for $\mathrm{Ru}, \mathrm{Rh}$, and $\mathrm{Pd}$ in $2 \% \mathrm{HCl}, \mathrm{Zn} / \mathrm{Na}(800 \mu \mathrm{g} / \mathrm{mL}$ for both), and $\mathrm{Pb}(1000 \mu$ $\mathrm{g} / \mathrm{mL}$ ) matrices. The latter two solutions were also $2 \%$ in $\mathrm{HCl}$ and were made from dilutions of the $1000 \mu \mathrm{g} / \mathrm{mL}$ SPEX ICP standards using the appropriate matrix as the diluent. $\mathrm{Pb}$ shows little or no interference in the determination of $\mathrm{Pd}$ and $\mathrm{Rh}$, but when the concentration of $\mathrm{Ru}$ is in the $\mathrm{ng} / \mathrm{mL}$ range it does have an appreciable effect. The $\mathrm{Zn} / \mathrm{Na}$ matrix has a very slight interference on all three noble metals, however when the concentrations of the metals are above $\sim 0.5 \mu \mathrm{g} / \mathrm{mL}$ the effect becomes insignificant.

In each of these cases, where there is a matrix effect the numbers are biased to the high side. Figures 2, 3, and 4 show that when there is a matrix effect the 1 inear response curves shift to the high side, maintaining their linearity and gradually sloping back to the $2 \% \mathrm{HCl}$ matrix curve. This indicates that the interfering matrix raises the background levels and remains constant. At very low concentration levels this background shift can be appreciable, but as the concentration of the analyte increases the shift becomes insignificant.

If rough numbers are acceptable in the $\mathrm{ng} / \mathrm{mL}$ range these matrix effects can be ignored, but if more accurate results are required these effects can be eliminated by matrix matching the calibrating standards. 
TABLE 3. The Effects of $\mathrm{Zn} / \mathrm{Na}$ and $\mathrm{Pb}$ Matrices on the ICP Determination of $\mathrm{Ru}$, Rh and $\mathrm{Pd}(\mathrm{a})$

Actual

Noble Metal Concentration $(\mu \mathrm{g} / \mathrm{mL})$

0.01

0.025

0.050

0.075

0.10

0.25

0.50

0.75

1.0

2.5

5.0

7.5

10.0

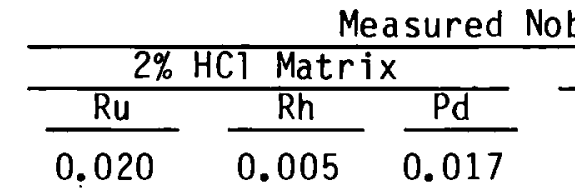

0.031

0.055

0.019

$0.048 \quad 0.051$

0.073

0.073

0.098

0.11

0.098

0.099

0.25

0.26

0.23

0.51

0.49

0.50

0.75

0.75

$1.00 .99 \quad 1.0$

2.62 .5

2.4

0.74

1.1

2.6

$5.04 .9 \quad 5.1$

5.0

7.67 .5

10.00 .0

7.6

9.9

7.4

10.1
$\frac{\frac{\mathrm{Zn} / \mathrm{Na} \text { Matrix }}{\mathrm{Ru}} \mathrm{Rh}}{\mathrm{Rh}}$

$\frac{\mathrm{Ru}}{0.042} \frac{\mathrm{Rh}}{0.020} \frac{\mathrm{Pd}}{0.045}$

$\begin{array}{lll}0.057 & 0.049 & 0.060\end{array}$

$\begin{array}{lll}0.079 & 0.064 & 0.085\end{array}$

$\begin{array}{lll}0.10 & 0.087 & 0.11\end{array}$

0.13

0.11

0.26

0.51

0.74

0.98

2.5

4.9

7.4
9.9

0.110 .14

0.250 .28

$0.48 \quad 0.52$

$0.74 \quad 0.76$

$1.0 \quad 1.1$

2.5

5.1

5.1

7.5

9.8
4.9

10.210.

\begin{tabular}{|c|c|c|}
\hline \multicolumn{3}{|c|}{ Pb Matrix } \\
\hline $\mathrm{Ru}$ & $\mathrm{Rh}$ & $\mathrm{Pd}$ \\
\hline 0.10 & 0.007 & 0.020 \\
\hline 0.16 & 0.053 & 0.051 \\
\hline
\end{tabular}

0.2

0.10

0.11

0.5

0.50

0.49

(a) A11 numbers represent the mean of ten $15-\mathrm{sec}$ burns. 


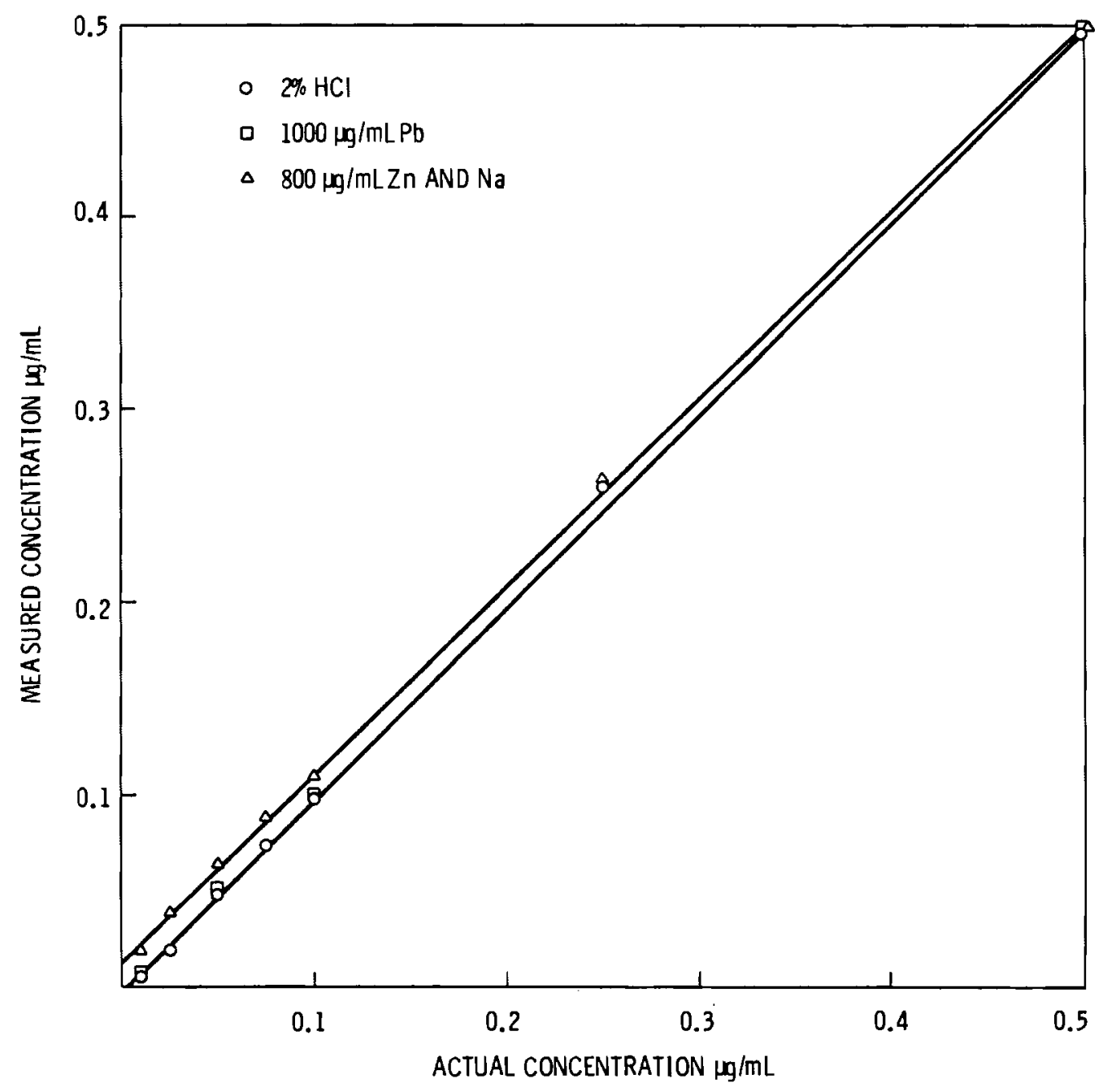

FIGURE 2. ICP Determination of Rh in Three Matrices 


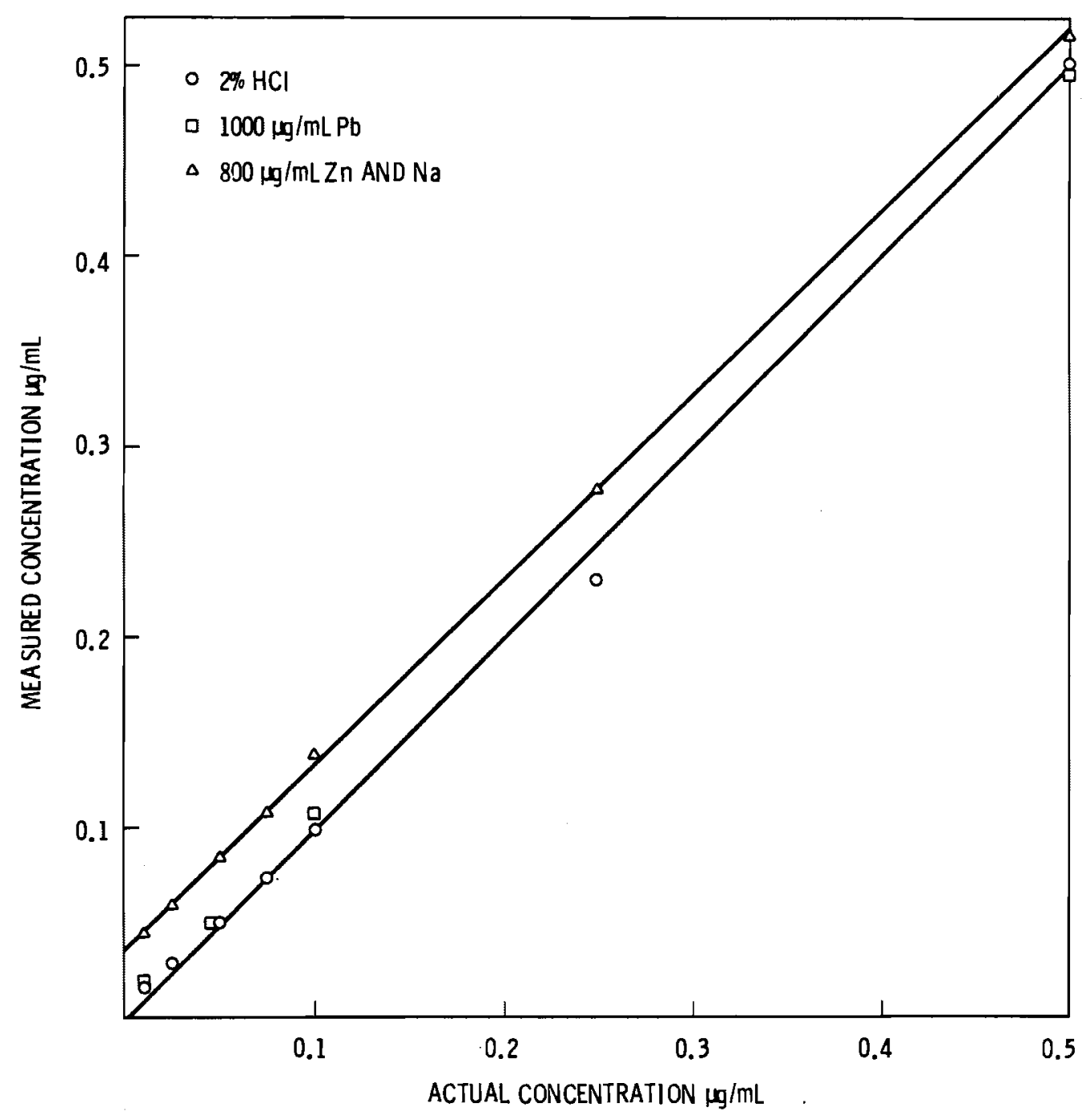

FIGURE 3. ICP Determination of Pd in Three Matrices 


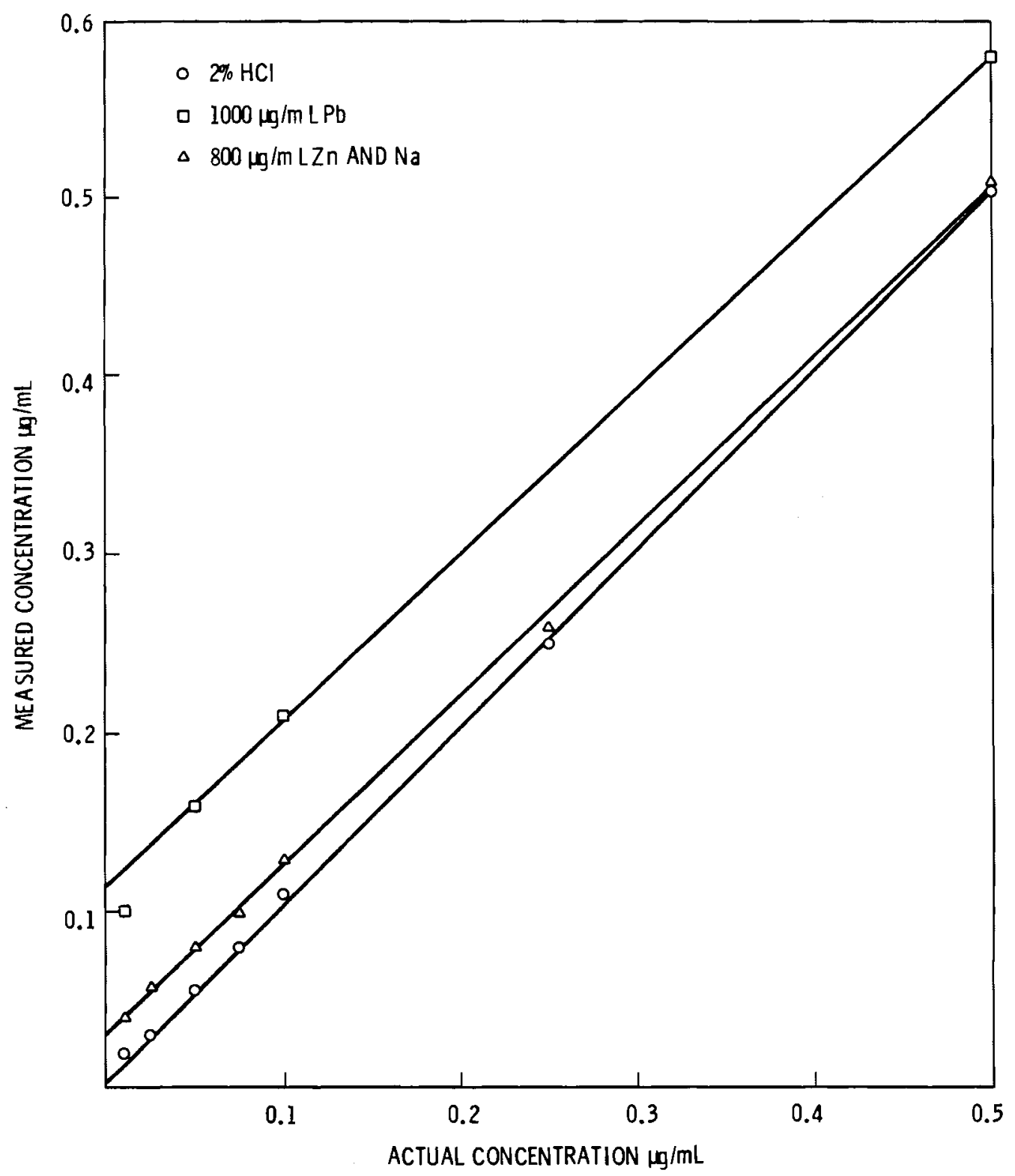

FIGURE 4. ICP Determination of Ru in Three Matrices 
NOBLE METAL ANALYSIS OF SOLID WASTE FORMS

Two methods for the analysis of noble metals $\mathrm{Ru}, \mathrm{Rh}$, and $\mathrm{Pd}$ in the glass or calcine waste forms are described in this section. The first method is based on a combination of ICP and $x$-ray fluorescence spectrometry and was developed as a fast, accurate technique that will work only on nonradioactive materials. The second method is based on a technique in which the noble metals are separated from the other components of the fission material and analyzed by ICP. Although this latter method is more complicated and takes more time than the first, it will work on radioactive and nonradioactive materials.

NOBLE METAL ANALYSIS OF NONRADIOACT IVE CALCINE AND GLASS

A fast and accurate analytical procedure was needed in the beginning of this work for the analysis of noble metals in both the PW-4b-7 calcine and the final glass waste form. The PW-4b-7 calcine, developed by PNL, is considered to be representative of commercial fission waste that contains a minimum amount of reprocessing chemicals (Mendel et a1. 1977). In the past, PNL has analyzed nonradioactive materials of this type by converting them into a 1 iquid form via a $\mathrm{Na}_{2} \mathrm{O}_{2} / \mathrm{NaOH}$ fusion (see Appendix for procedure) and performing the subsequent analysis on the ICP. Table 4 gives the results of such an analysis of the $\mathrm{PW}-4 \mathrm{~b}-7$ calcine.

The elements represented in Table 4 were present on the direct reading polychromator being used by this laboratory. A scanning monochromator is available for looking at other elements not present on the direct reader, but spectral interferences from the other components of the calcine prevented this method from being used to obtain a reliable analysis for Pd or Rh. Since that time $\mathrm{Pd}$ and Rh channels have been added to the direct reader and (because of its superior resolving power) analysis for Rh directly from the fused calcine in now possible. However, because there is a large interference (170\%) from Samarium (Sm) (interferences of that size cannot be reliably corrected for) analysis for Pd using the $360.9-\mathrm{nm}$ line cannot be made directly from the fused calcine. 
TABLE 4. ICP Analysis of the Calcine PW-4b-7

\begin{tabular}{|c|c|}
\hline El ement & wt\% \\
\hline$B$ & 0.04 \\
\hline $\mathrm{Ba}$ & 2.3 \\
\hline $\mathrm{Ca}$ & 0.32 \\
\hline $\mathrm{Cd}$ & 0.17 \\
\hline $\mathrm{Ce}$ & 5.2 \\
\hline $\mathrm{Cr}$ & 0.56 \\
\hline $\mathrm{Eu}$ & 0.34 \\
\hline $\mathrm{Fe}$ & 2.3 \\
\hline $\mathrm{Gd}$ & 0.60 \\
\hline La & 2.5 \\
\hline $\mathrm{Mg}$ & 0.07 \\
\hline$M n$ & 0.03 \\
\hline Mo & 7.5 \\
\hline $\mathrm{Nd}$ & 7.5 \\
\hline $\mathrm{Ni}$ & 0.21 \\
\hline$P$ & 0.60 \\
\hline $\mathrm{Ru}$ & 4.2 \\
\hline$S i$ & 4.5 \\
\hline Sr & 1.8 \\
\hline $\mathrm{Te}$ & 0.89 \\
\hline $\mathrm{Te}$ & 0.04 \\
\hline $\mathrm{Zn}$ & 0.04 \\
\hline $\mathrm{Zr}$ & 7.6 \\
\hline
\end{tabular}

The initial analyses for Pd and Rh were obtained by a combination of ICP and $x$-ray fluorescence spectrometry. A Spectrace $440^{\circledR}$ energy dispersion unit was the type of $x$-ray used in this work.

(B) Spectrace is a registered trademark of United Scientific of Mountain View, California. 
In the $x$-ray fluorescence spectrum the noble metals Ru, Rh, and $\mathrm{Pd}$ have adjacent peaks. Peak area ratios of $\mathrm{Ru} / \mathrm{Rh}$ and $\mathrm{Ru} / \mathrm{Pd}$ are obtained by counting the solid sample on the $x$-ray. Because these peak area ratios correspond very closely to concentration ratios, quantitative concentration values can be calculated for Rh and Pd by using'the Ru concentration value obtained from the ICP.

Figure 5 shows the $x$-ray spectrum for this calcine over the energy region of 14 to $25 \mathrm{KeV}$. Each of the elements shown has two peaks corresponding to the $K_{\alpha}$ and $K_{\beta}$ energy transitons. The Mok $K_{\beta}$ interferes with the Ruk $\alpha$ peak so the MoK $_{\beta}$ must be removed from the spectrum before peak area ratios can be obtained. Figure 6 shows this same spectrum after the MoK $_{\alpha}$ and $K_{\beta}$ peaks have been mathematically stripped away by the controlling computer. From this spectrum, peak area ratios of 5.93 and 1.56 are obtained for Ru/Rh and Ru/Pd, respectively. Using these values and the original Ru ICP concentration of $4.2 \mathrm{wt} \%$, the following concentrations for Rh and Pd are calculated:

$$
\begin{array}{rlrl}
\mathrm{Ru} / \mathrm{Rh} & =5.93=4.2 w t \% / \mathrm{Rh} w t \% & \mathrm{Rh}=0.71 w t \% \\
\mathrm{Ru} / \mathrm{Pd}=1.56=4.2 w t \% / \mathrm{Pd} w t \% & \mathrm{Pd}=2.7 w t \%
\end{array}
$$

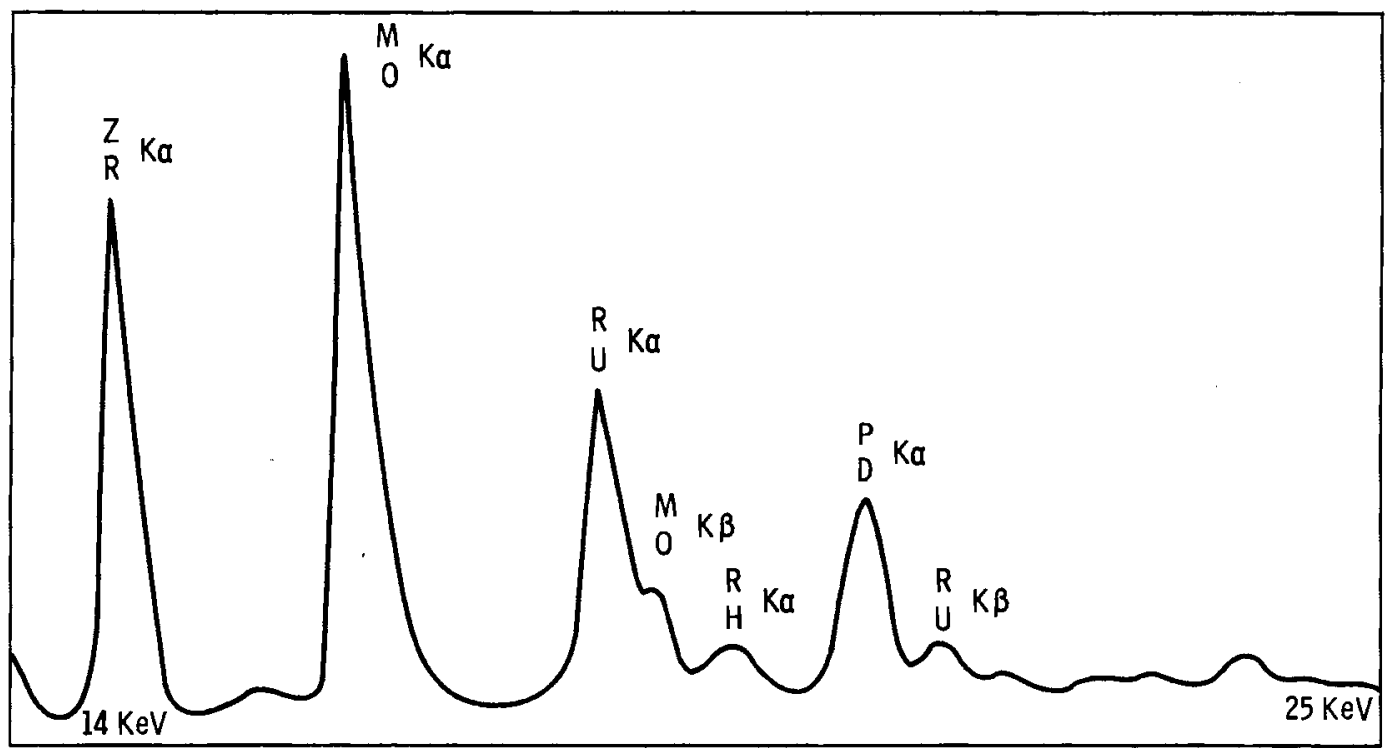

FIGURE 5. X-Ray Spectrum of the PW-4b-7 Calcine in the 14 to $25 \mathrm{KeV}$ Energy Region 


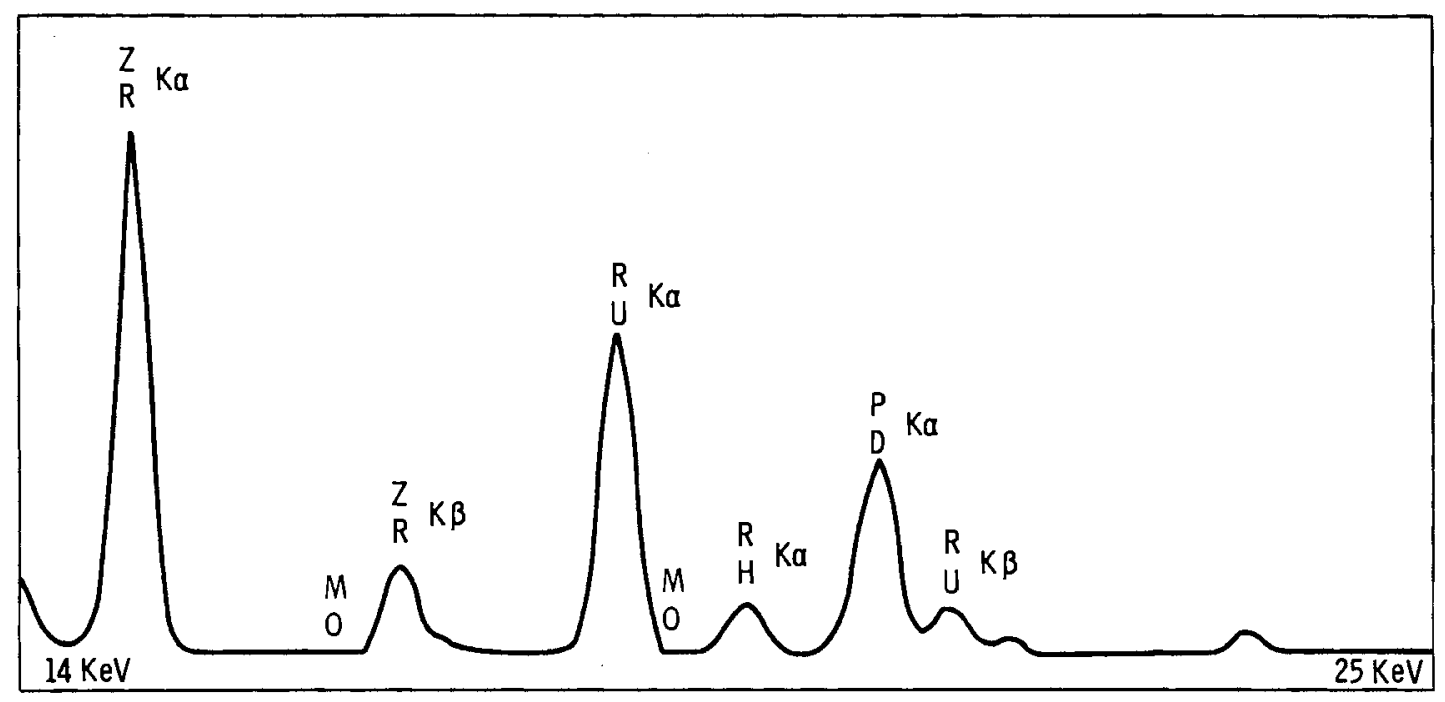

FIGURE 6. PW-4b-7 Calcine X-Ray Spectrum With the MoK $K_{\alpha}$ and $K_{\beta}$ Peaks Removed

Although this method works quite well for nonradioactive materials (both calcine and glass), it will not work for highly radioactive materials. The solid-state detector used by the Spectrace $440 \AA$ would be overloaded by the high-level background radiation created by the naturally radioactive materials. Therefore, another approach is needed for the analysis of the actual radioactive materials.

NOBLE METAL ANALYSIS OF FISSION PRODUCT CALCINE AND GLASS

Di rect ICP analysis for Ru and $\mathrm{Rh}$ in the fused calcine or glass is possible using the ICP lines of emission addressed in this report but because of the spectral interferences involved, good quantitative numbers cannot be obtained for $\mathrm{Pd}$. If, however, the noble metals can be separated from the interfering components of the fission waste, ICP analysis can be used for all three elements. Another benefit of such a separation would be the removal of most of the highly radioactive fission products thus leaving a sample that would be safer and easier to handle.

Two criteria had to be considered for the separation technique: 1) the technique must quantitatively remove $\mathrm{Ru}, \mathrm{Rh}$, and $\mathrm{Pd}$ from the interfering components present in the fission waste, and 2) the technique must be simple in 
application because it will eventually be carried out in a hot cell with manipulators. Of the separation techniques found in the literature (Beamish 1966; Campbell 1968; Zolotov, et al. 1978; Vorbeva, et al. 1974; Vasilyeva, et a1. 1975; Ginzburg, et a 1. 1975) only two met both of these criteria. One was a liquid/liquid extraction procedure using the compound para-n-octyl aniline, but its commercial unavailability coupled with a shortage of time precluded its use. The second technique was a reduction method in which the noble metals are reduced to their metallic state, thus precipitating out of solution. Al though several reductants were possible, after a preliminary investigation metallic Zn was chosen.

In the past, the determination of noble metals by $\mathrm{Zn}$ reduction has not been an accurate or reliable method because it was usually has been applied as a gravimetric technique (Beamish, 1966, p. 254). In this technique an isolated noble metal is reduced with excess $\mathrm{Zn}$ from a weakly acidic $\mathrm{HCl}$ medium. This excess $\mathrm{Zn}$ is washed away with dilute $\mathrm{HCl}$ and the remaining precipitate is weighed as the metal. Because $\mathrm{Zn}$ is easily attacked by $\mathrm{HCl}$ and because the noble metals are considered to be inert toward corrosion from $\mathrm{HCl}$, this selective leaching would appear to be a simple process. However, the degree of corrosive action that $\mathrm{HCl}$ has on $\mathrm{Zn}$ and the noble metals under these conditions depends on the impurities present at the time of the contact (Binzburg, et al. 1975, p. 14-16). Therefore, predictions concerning the degree of corrosiveness that $\mathrm{HCl}$ will have on $\mathrm{Zn}$ and the noble metals cannot be made with any reasonable degree of certainty.

When the above procedure is used under the proper conditions, the reduction of the noble metals is complete. In addition, only a few other elements are reduced by metallic $Z n$ in an acid medium. Thus, the first criterion, the one step quantitative removal of $\mathrm{Ru}$, $\mathrm{Rh}$, and $\mathrm{Pd}$ from the interfering constituents of the fission product waste, has been met. As for the second criterion, the ease of application, only a few very basic laboratory techniques are required.

Figure 7 shows a schematic representation of the analysis of noble metals in calcine or glass. In brief, the initial solid sample is fused into solution 


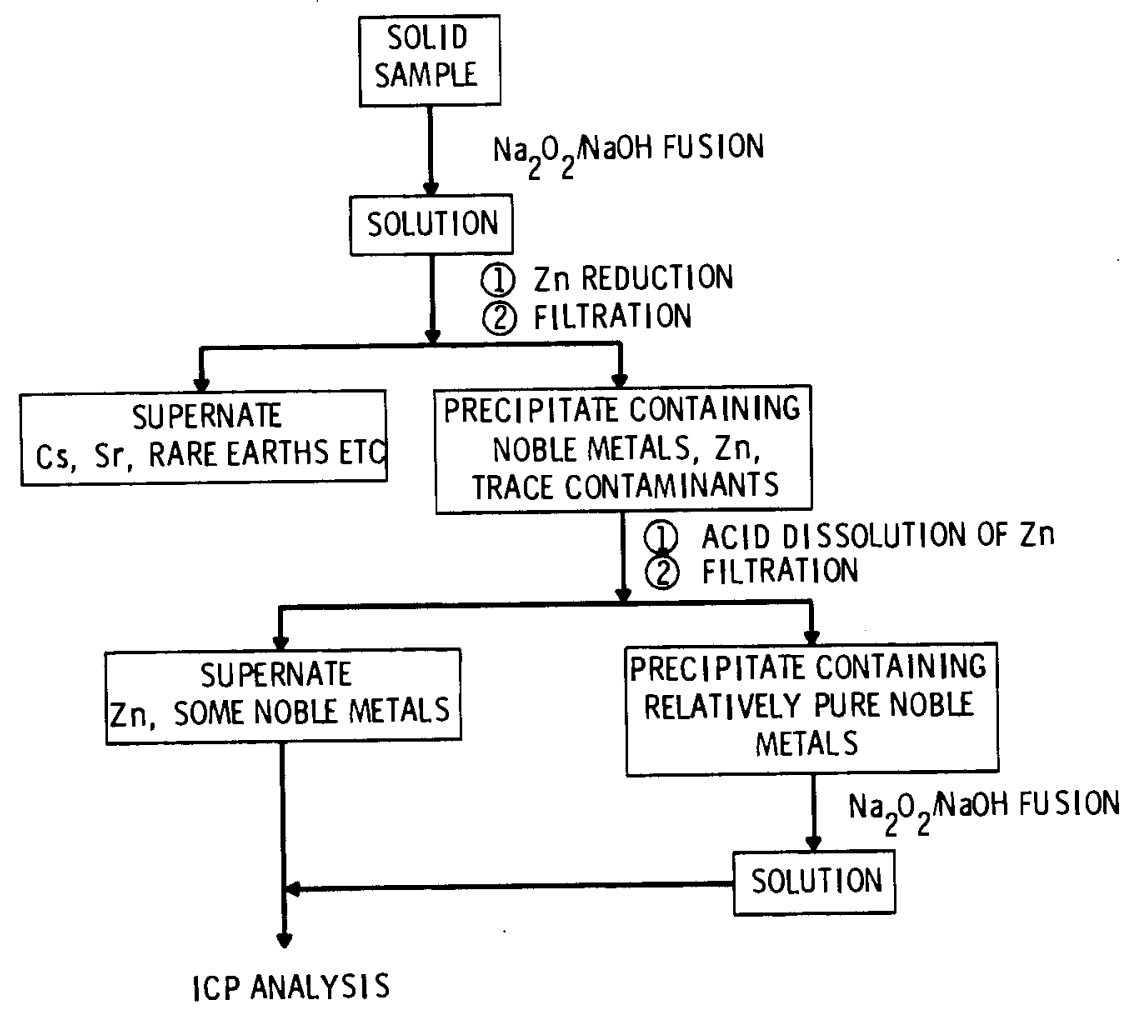

FIGURE 7. Schematic Representation of the Analysis of Noble Metals in Calcine or Glass

and acidified with $\mathrm{HCl}$. Zn is added and the solution is allowed to stand 12 to $16 \mathrm{~h}$. The precipitate, which at this point contains the noble metals, some left-over $\mathrm{Zn}$, and some trace contaminants, is separated from the supernate (discard this solution) and washed with $\mathrm{HCl}$ (save this solution) to remove the excess $\mathrm{Zn}$. It is then fused back into solution, acidified with $\mathrm{HCl}$, and added to the $\mathrm{HCl}-\mathrm{Zn}$ wash solution. This final solution is then to an appropriate volume and a portion of this is removed from the hot cell for ICP analysis. (See appendix for the detailed procedure.)

RESULTS AND DISCUSSION

To evaluate the analytical reduction procedure, a set of multiple noble metal analyses of the $\mathrm{PW}-4 \mathrm{~b}-7$ calcine as well as a series of spike recovery experiments were completed. The spike recovery experiments were carried out by spiking a fused calcine with $5000 \mu \mathrm{g}$ of each of the noble metals. The 
composition of the fused calcine was similar to the PW-4b-7 calcine except that it contained no noble metals. Tables 5 and 6 show the results of this work.

Rh gave the best spike recovery results; the Pd numbers are a little high and the Ru numbers are a little low. As mentioned earlier, the rare earth Sm has an extremely strong spectral interference with the Pd $360.9 \mathrm{~nm}$ Iine.

Because $\sim 5 \%$ of the rare earths $\mathrm{Ce}$ and $\mathrm{Nd}$ were carried all the way through the procedure to the final solution, we can assume that some of the rare earth $\mathrm{Sm}$ carried through also. This would explain the high Pd numbers. Some evidence exists that small amounts of Ru can be lost during base fusions at temperatures above $350^{\circ} \mathrm{C}$ (Ginzburg, et a 1. 1975, p. 21). The temperatures at which the fusions described in this report were carried out $\left(550^{\circ} \mathrm{C}\right)$ could partially explain the low Ru numbers.

TABLE 5. Noble Metal Analysis of the PW-4b-7 Calcine Via the Reduction Procedure (wt\%)

\begin{tabular}{|c|c|c|c|}
\hline Samp le & $\mathrm{Ru}$ & $\mathrm{Rh}$ & $\mathrm{Pd}$ \\
\hline 1 & 3.9 & 0.83 & 2.8 \\
\hline 2 & 3.8 & 0.83 & 2.7 \\
\hline 3 & 4.0 & 0.85 & 2.9 \\
\hline 4 & 4.0 & 0.84 & 3.0 \\
\hline 5 & 3.7 & 0.81 & 2.9 \\
\hline 6 & 3.9 & 0.83 & 2.8 \\
\hline
\end{tabular}

TABLE 6. Noble Metal Spike Recoveries (\% recovered)

\begin{tabular}{ccrc} 
Sample & & $\frac{R u}{P 0}$ & $\frac{R h}{P d}$ \\
\hline 1 & & 90 & $\frac{100}{107}$ \\
3 & 93 & 95 & 110 \\
4 & 87 & 98 & 105 \\
5 & 91 & 100 & 113 \\
6 & 90 & 95 & 110 \\
3 & 92 & 97 & 108
\end{tabular}


If the trends that discovered in the spike recovery results are present in the analysis of the PW-4b-7 calcine, the Rh numbers should be near the true value. The Ru numbers are probably $\sim 10 \%$ low and the Pd numbers are $\sim 10 \%$ high. With these adjustments taken into account, values of $4.2 \mathrm{wt} \%, 0.83 \mathrm{wt} \%$ and $2.6 \mathrm{wt} \%$ are obtained for $\mathrm{Ru}, \mathrm{Rh}$ and Pd, respectively. The ICP/x-ray fluorescence analysis procedure gave noble metal values of $4.2 \mathrm{wt} \%, 0.71 \mathrm{wt} \%$ and 2.7 wt\% which compare very closely to the reduction procedure numbers. 
When lead metal buttons containing the noble metals are dissolved in dilute nitric acid, a fine, dark, acid-insoluble precipitate is formed. An $x$-ray diffraction analysis of this precipitate reveals a complex pattern in which diffraction lines for metallic Ru, Rh, and Pd can be identified as well as several other lines which annot be identified. Samples of the noble metals in both $\mathrm{Bi}$ and $\mathrm{Pb}$ "solvent metal" matrices were submitted for scanning electron microscope (SEM) and electron microprobe analysis. The photographs of these analysis are shown in Figures 8, 9, 10 and 11 .

The electron microprobe analysis of both the $\mathrm{Bi}$ and $\mathrm{Pb}$ matrices show that $\mathrm{Ru}$ is precipitated as small aggregates of relatively pure metal. The microprobe photograph of the base metals shows a void area, indicating very low concentrations where the Ru has precipitated. These photographs indicate that there is little tendency for the Ru to form intermetallic compounds with either $\mathrm{Bi}$ or $\mathrm{Pb}$. The electron microprobe scans of $\mathrm{Rh}, \mathrm{Pd}$, and $\mathrm{Te}$ in the $\mathrm{Bi}$ metal sample show two definite phases: a polygonal phase rich in $\mathrm{Rh}, \mathrm{Pd}$, and $\mathrm{Te}$, and a rod-shaped phase rich in relatively pure $\mathrm{Pd}$. In the $\mathrm{Pb}$ "solvent metal," the $\mathrm{Rh}$ and Pd precipitate throughout the matrix. This diffuse concentration could indicate intermetallic compound formation with the solvent metal (Ginzburg, et a1. 1975, p. 14-16). When the $\mathrm{Pb}$ buttons are dissolved in dilute nitric acid, the Pd and Rh are slightly soluble. The degree of solubility, which varies from sample to sample, probably is determined to some extent by the degree of noble metals' dispersity, the formation of intermetallic compounds, and the presence of foreign impurities.

Thus, the metal buttons are not homogeneous in composition (with respect to the noble metals); therefore, sampling could be a possible source of error. Because of the small metal buttons that are generated in the laboratory scale process, this does not represent a problem (i.e., the whole sample can be dissolved and analyzed). When the process is developed to pilot scale and then to production scale, the size of the metal buttons produced will also increase. As this happens the problem of obtaining a representative sample also could increase, making a reliable analysis more difficult to obtain. 


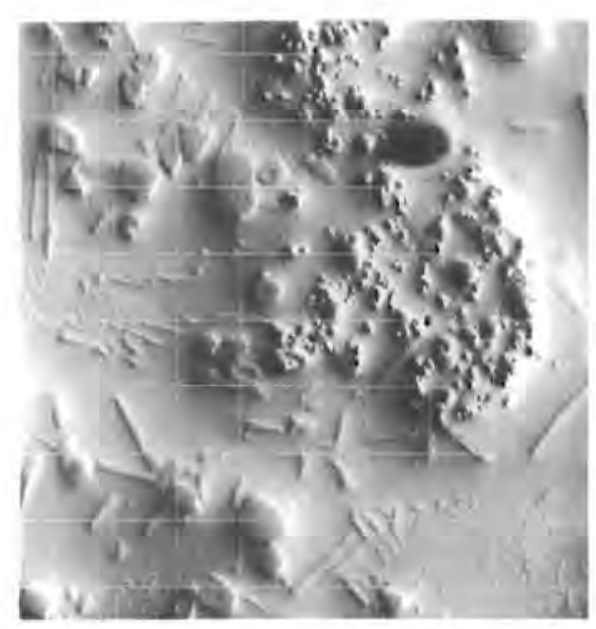

SEM OF Bi BUTTON

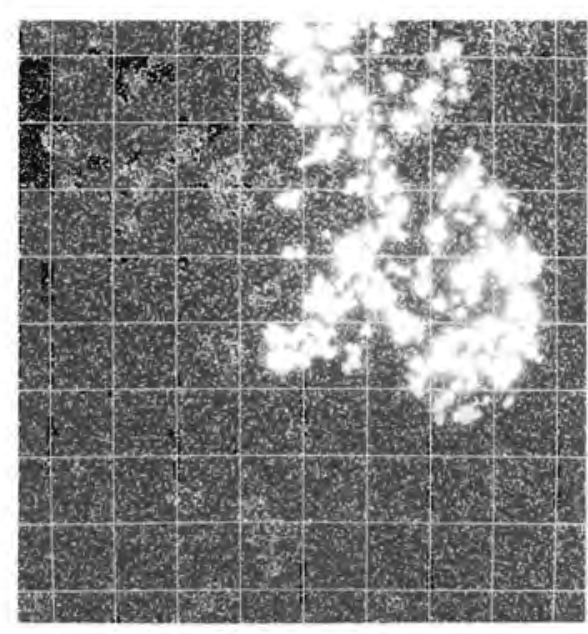

MICROPROBE OF RU IN Bi

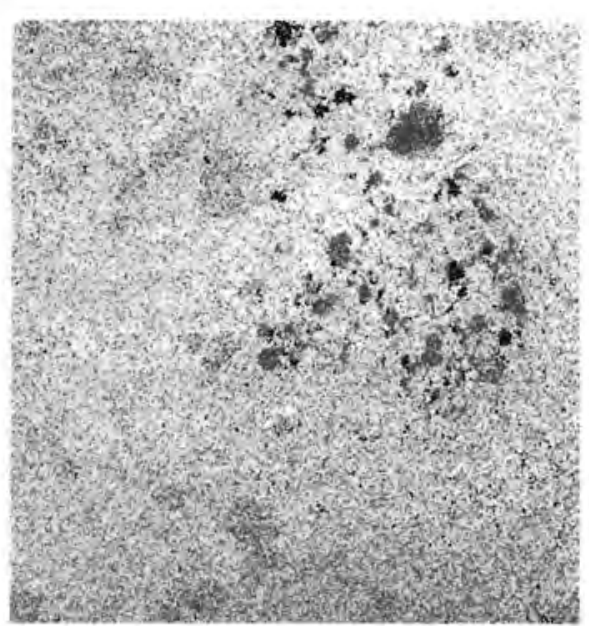

MICROPROBE OF Bi

SCALE: $\sqcup$

$10 \mu \mathrm{m}$

FIGURE 8. Microstructure of Bismuth "Solvent Metal" Button 


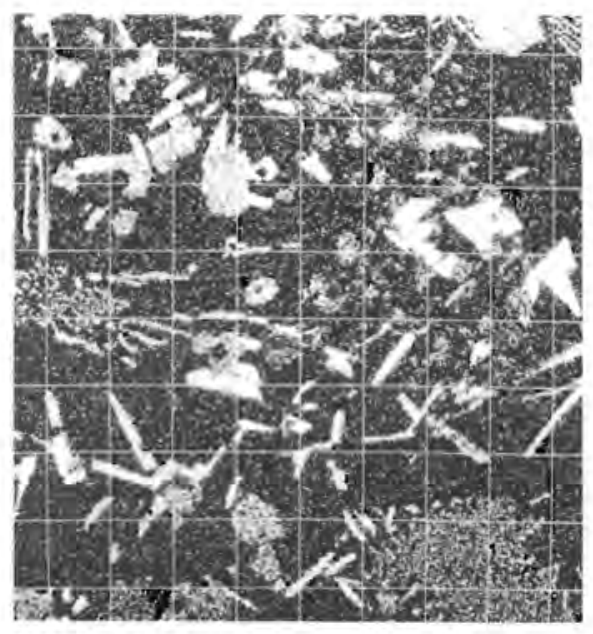

MICROPROBE OF Pd IN Bi

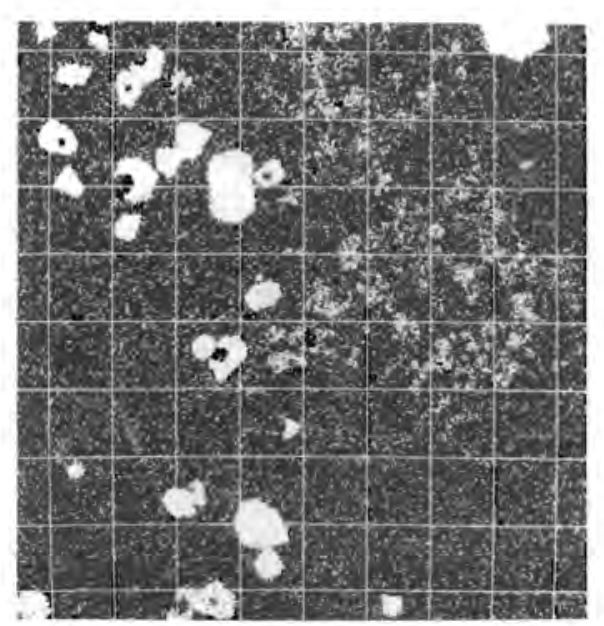

MICROPROBE OF Rh IN Bi

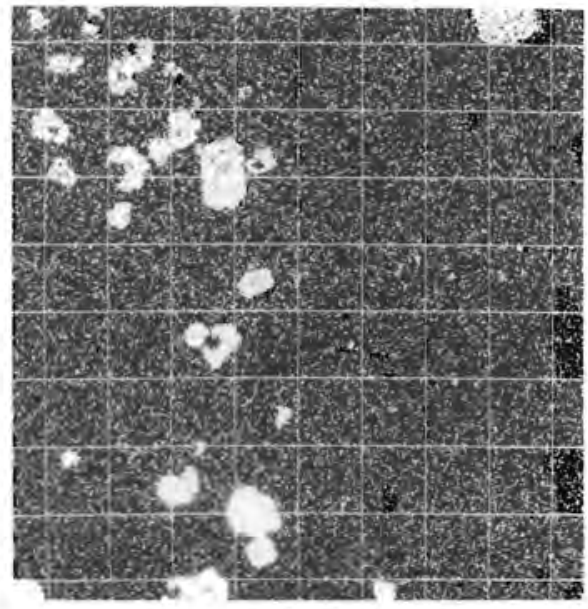

MICROPROBE OF Te IN Bi

\section{SCALE: $\square$ \\ $10 \mu \mathrm{m}$}

FIGURE 9. Microstructure of Bismuth "Solvent Metal" Button 


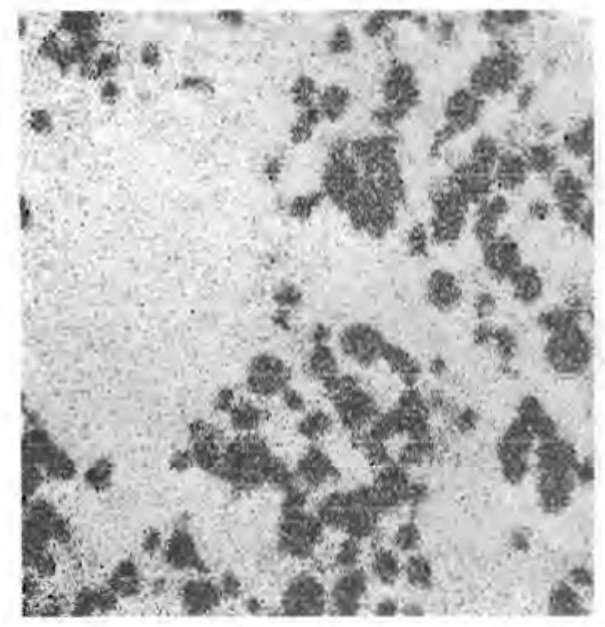

MICROPROBE OF Pb BUTTON

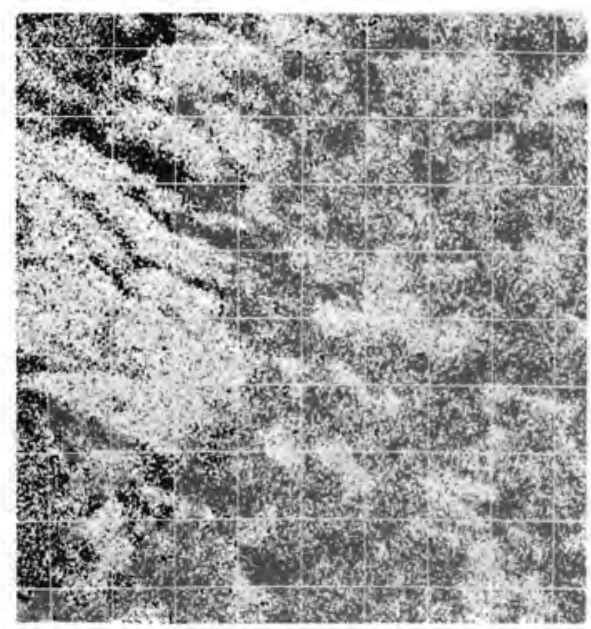

MICROPROBE OF Pd IN Pb

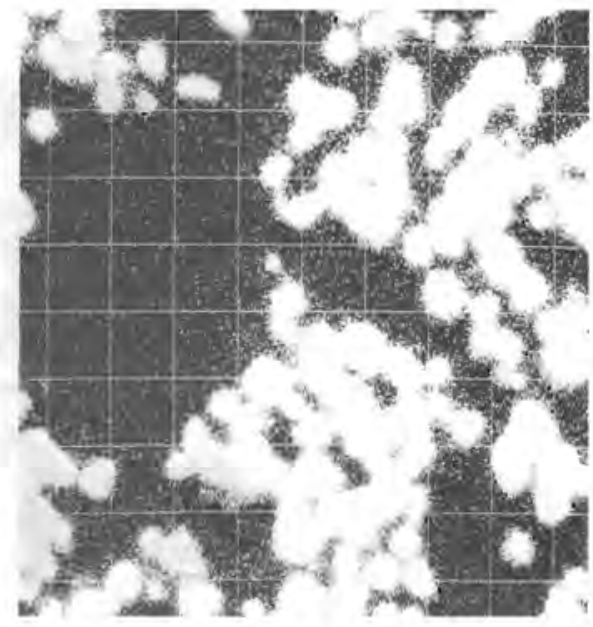

MICROPROBE OF RU IN Pb

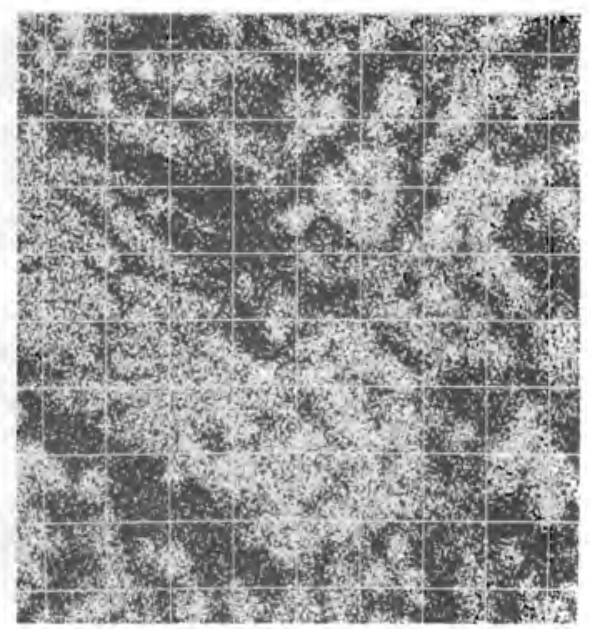

MICROPROBE OF Rh IN Pb

SCALE:

$10 \mu \mathrm{m}$

FIGURE 10. Microstructure of Lead "Solvent Meta7" Button 


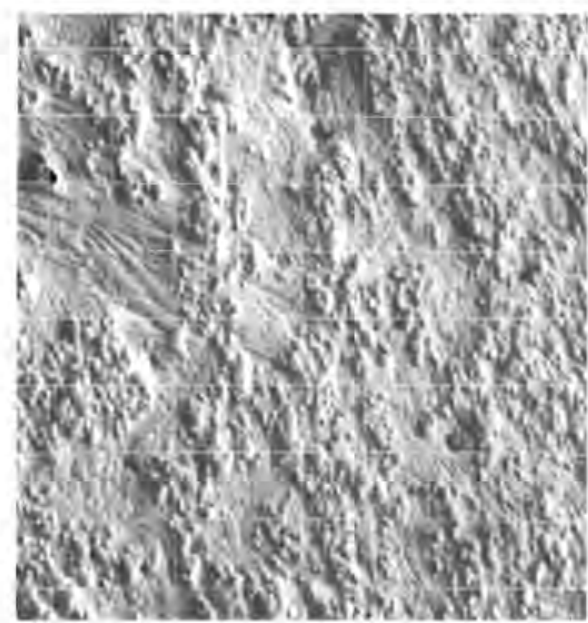

SEM OF Pb BUTTON

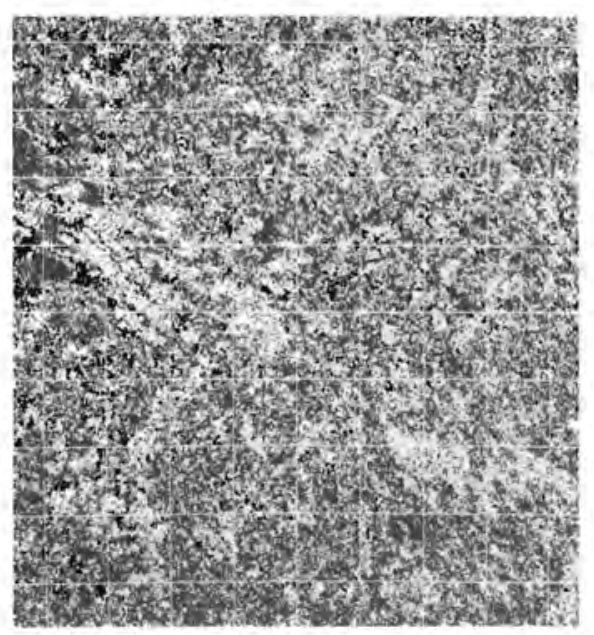

MICROPROBE OF Pd IN Pb

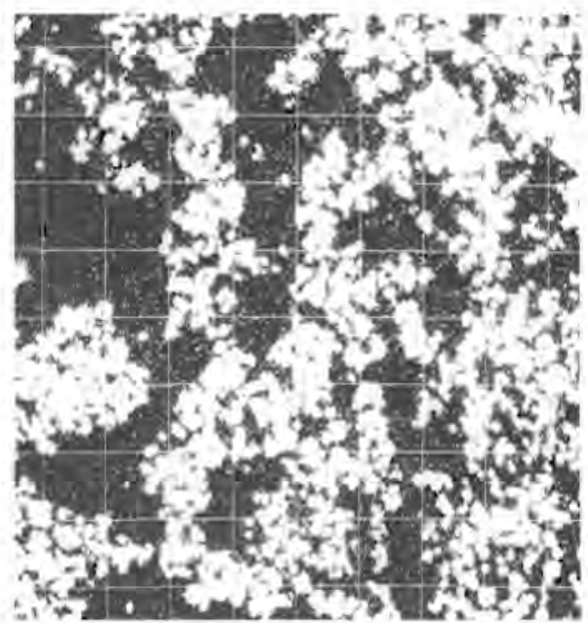

MICROPROBE OF RU IN Pb

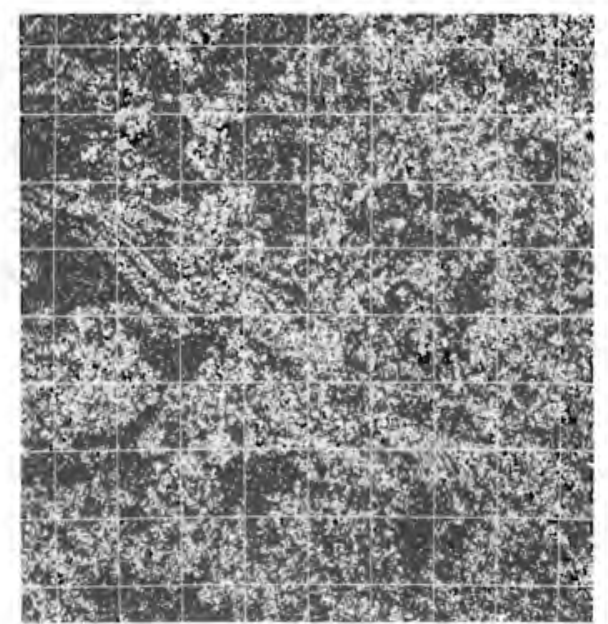

MICROPROBE OF Rh IN Pb

SCALE: $\sqcup$

$10 \mu \mathrm{m}$

FIGURE 11. Microstructure of Lead "Solvent Metal" Button 
When the noble metal extraction research began, several metals $(\mathrm{Pb}, \mathrm{Bi}$, $\mathrm{Sb}, \mathrm{Sn}$, and $\mathrm{Cu}$ ) were considered as possible "solvent metals." Toward the completion of the work it became apparent that $\mathrm{Pb}$ was probably going to be the metal of choice; thus, only the analysis procedure for the Pb matrix is given. The analytical schemes for the other solvent metals are basically similar, with the only diffrences being the types and amounts of acids used in the button dissolution step.

A weighed representative sample of lead metal is placed in a $400 \mathrm{~mL}$ beaker and at $\sim 150 \mathrm{~mL}$ of $2 \mathrm{M} \mathrm{HNO}_{3}$ is added for each $5 \mathrm{~g}$ of sample. The acid solution can either be agitated to facilitate dissolution or allowed to stand for $\sim 16 \mathrm{~h}$. Once the lead has completely dissolved, the solution is filtered (by vacuum) through a $0.45-\mu \mathrm{m}$, cellulose-acetate membrane filter.

The filtrate is diluted to $250 \mathrm{~mL}$ in a volumetric flask. A $10-\mathrm{mL}$ to $100 \mathrm{~mL}$ dilution (using demineralized water) of this solution can be analyzed for the noble metals by ICP. The precipitate on the membrane filter is transferred into an alumina crucible. Next, $1.0 \mathrm{~mL}$ of a $50 \% \mathrm{NaOH}$ is added to the sample and the solution is slowly evaporated $t$ dryness on a hot plate. After drying, $1 \mathrm{~g}$ of $\mathrm{Na}_{2} \mathrm{O}_{2}$ is added to the sample and it is fused in a muffle furnace at $550^{\circ} \mathrm{C}$ for $20 \mathrm{~min}$. After the fusion period, the sample is removed from the furnace and is cooled to room temperature on an asbestos sheet. The cooled fused mixture is leached with $\sim 25 \mathrm{~mL}$ of water (added by drop) and transferred into a $250-\mathrm{mL}$ volumetric flask. Two $25-\mathrm{mL}$ portions of $40 \% \mathrm{HCl}$, followed by one $25-\mathrm{mL}$ portion of deionized water are used as rinses. This solution is boiled gently for $\sim 1$ to $2 \mathrm{~min}$., cooled to room temperature, and diluted to volume with demineralized water. A $10 \mathrm{~mL}$ to $100 \mathrm{~mL}$ dilution of this solution is then ready for ICP noble metal analysis. 


\section{REFERENCES}

Beamish, F. E. 1966. The Analytical Chemistry of the Noble Metals. Pergamon Press Ltd., Oxford, London.

Campbel1, M. H. 1968. "A Rapid Determination of Rhodium and Palladium Using Liquid-Liquid Extraction with Tricapryl Monomethyl Ammonium Chloride and Fl ame Photometry." Analytical Chemistry. 40:6.

Cruickshank, Z., and H. C. Munro. 1979. "X-Ray Fluorescence Determination of Platinum and Palladium in Platinum Concentrates Using a Solution Technique." Analyst. 104:1050-1054.

Fassel, V. A. 1979. "Simultaneous or Sequential Determination of the El ements at all Concentration Levels--The Renaissance of an 01d Approach." Analytical Chemistry. 51:1290.

Fasse1, V. A. 1978. Science. 202:183.

Ginzburg, S. I., et a1. 1975. Analytical Chemistry of Platinum Metals. John Wiley and Sons, Inc., New York.

Hanson, T. J., and R. D. Ediger. 1980. "Combining AA and ICP." American Laboratory. 116-123.

Jensen, G. A. 1980. Recovery and Use of Fission Product Noble Metals. PNL-SA-8358, Pacific Northwest Laboratory, Richland, Washington.

Mendel, J.E., et a1. 1977. Annual Report on the Characteristics of High-Level Waste Glasses. BNWL-2252, Pacific Northwest Laboratory, Richland, Washington.

Oumo, P. R., and E. Ni eboer. 1979. "Determination of Microgram Amounts of Precious Metals Using X-Ray Fluorescence Spectrometry." Analyst. 104: 1037-1049.

Sandoz, D. P. 1966. The Determination of Rhodium and Palladium by Atomic Ab sorption Spectrometry. ISO-593, ISOCHEM INC., RichTand, Washington.

Scharborough, J. M. 1969. "Determination by Atomic Absorption of Molybdenum, Ruthenium, Palladium, and Rhodium in Uranium Alloys." Analytical Chemistry. 41:250-254.

Vasilyeva, A. A., et al. 1975. "Extractive Concentration of Platinum-Group Elements and Their Determination by Atomic-Absorption Sectrophotometry." Ta lanta. 22:745-749. 
Vorbeva, G. A., et a1. 1974. "Extraction of the Noble Metals for Their Group Separation and Subsequent Spectrographic Determination." Zhurnal

Analiticheskoi Khimi. 29:497-505.

Zolotov, Y. A., et al. 1978. "Solvent Extraction of Noble Metals with Derivatives of Thiourea." Analytical Chimica Acta. 100:613-618. 


\section{APPENDIX}

SODIUM PEROXIDE/SODIUM HYDROXIDE FUSION PROCEDURE

AND

NOBLE METAL SEPARATION PROCEDURE 


\section{SODIUM PEROXIDE/SODIUM HYDROXIDE FUSION PROCEDURE}

Accurately weigh (to the nearest milligram) between 0.25 and $0.75 \mathrm{~g}$ of finely ground sample into an alumina crucible containing $2 \mathrm{~g}$ of $\mathrm{Na}_{2} \mathrm{O}_{2}$ and $1 \mathrm{~g}$ of $\mathrm{NaOH}$ and mix well. As in any fusion method, solid samples should be ground to less than 100-mesh seive size to facilitate complete dissolution during the fusion step.

Slowly heat this mixture on a hot plate to remove any residual moisture. When the mixture is dry, place it in a muffle furnace at $550^{\circ} \mathrm{C}$ for $20 \mathrm{~min}$. After this fusion period, remove the crucible from the furnace and allow it to cool slowly to room temperature on an asbestos pad. (Note: Do not place the hot alumina crucible directly on a cold, metal surface because the thermal shock will crack it.) When the crucible is cooled, slowly add water (by drop) until the more vigorous reaction has subsided. Then bring the total volume up to $\sim 25 \mathrm{~mL}$. This water-leached sample is transferred to a $250-\mathrm{mL}$ volumetric flask, using two $25-\mathrm{mL}$ portions of $40 \% \mathrm{HCl}$ and two $25-\mathrm{mL}$ portions of deionized water as rinses. The acidified sample is then heated to a slow boil on a hot plate and cooled back down to room temperature. After the solution has cooled, it is brought up to volume with deionized water, and a $10-\mathrm{mL}$ to $100-\mathrm{mL}$ dilution of this solution can be run on the ICP. 
$\checkmark$

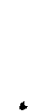

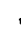

-

,

$\leftarrow$ 


\section{NOBLE METAL SEPARATION PROCEDURE}

The preceding $\mathrm{Na}_{2} \mathrm{O}_{2} / \mathrm{NaOH}$ fusion procedure is used to dissolve the solid sample. After the cooled, fused, crucible contents have been leached with water, they are transferred to a clean 250-mL beaker, using two $20-\mathrm{mL}$ portions of $40 \% \mathrm{HCl}$ and one $20-\mathrm{mL}$ portion of deionized water as rinses. The solution is heated to a slow boil for 1 to $2 \mathrm{~min}$ and then cooled to room temperature. once cooled, the final volume is brought up to $120 \mathrm{~mL}$ with deionized water. Six grams of 20-mesh granular $\mathrm{Zn}$ is then added to the sample, and this solution is allowed to stand for a period of 12 to $16 \mathrm{~h}$. After the reduction period, the solution is slowly brought up to a temperature of 60 to $70^{\circ} \mathrm{C}$ over a period of 10 to $15 \mathrm{~min}$ and then is removed and allowed to cool. The supernate, plus the suspended precipitate, is decanted from the heavier $\mathrm{Zn}$ granules and filtered through a $0.45-\mu \mathrm{m}$, cellulose-acetate membrane filter by vacuum. The $Z n$ granules are washed with three $10-\mathrm{mL}$ portions of deionized water after the initial supernate has been decanted off. The filtrate, which contains most of the dissolved $Z n$ and fission products, is discarded. The excess granular $\mathrm{Zn}$, which is still in the beaker, is dissolved with $50 \mathrm{~mL}$ of $40 \% \mathrm{HCl}$ and is brought to a boil on a not plate. While still hot, this solution is poured over the noble metal-bearing filter paper and is allowed to stand with no vacuum being applied. After 1 to 2 min, the vacuum is reapplied and the resulting filtrate is transferred to a $250-\mathrm{mL}$ volumetric flask and saved. The filter membrane is then removed from the vacuum filtration apparatus and transferred into an alumina crucible. About $1 \mathrm{~mL}$ of a $50 \% \mathrm{NaOH}$ solution is added to the crucible, and low heat is applied for a period of $\sim 1 \mathrm{~h}$, or until all of the water has been driven off. Once dry, $\sim \mathrm{g}$ of $\mathrm{Na}_{2} \mathrm{O}_{2}$ is added, and the mixture is transferred to a muffle furnace where it is fused at $550^{\circ} \mathrm{C}$ for $20 \mathrm{~min}$.

After the fusion period, when the crucible has cooled to room temperature, water is slowly added by drop until the vigorous degassing has subsided, and then the total volume is brought up to about $25 \mathrm{~mL}$. Using two $20-\mathrm{mL}$ portions of $40 \% \mathrm{HCl}$ followed by one $20-\mathrm{mL}$ portion of water, transfer the contents of the crucible to the original $250-\mathrm{mL}$ volumetric flask in which the 
granular Zn dissolution solution was saved. This solution is brought to a slow boil, cooled to room temperature, and diluted to volume using

demineralized water. A $10-\mathrm{mL}$ to $100-\mathrm{mL}$ dilution of this solution can then be analyzed for Ru, Rh, and Pd on the ICP.

A.4 


\section{DISTRIBUTION}

No. of

Copies

\section{OFFSITE}

W. H. McMullen

DOE Albuquerque Operations Office

P. 0. Box 5400

Albuquerque, NM 87185

2 R. Y. Lowrey

DOE A.buquerque Operations Office

P. 0. Box 5400

Albuquerque, NM 87185

J. 0 . Neff

Department of Energy

Columbus Program Office

505 King Avenue

P. 0. Box 5400

Columbus, $\mathrm{OH} 43201$

C. W. Edington

ER-70, GTN

Office of the Deputy

Assistant Secretary

Nuclear Materials

Germantown, MD 20545

J. P. Hamric

DOE Idaho Operations Office

550 2nd Street

Idaho Falls, ID 83401

F. C. Gilbert

DP-10, GTN

Office of the Deputy

Assistant Secretary

Nuclear Materials

Germantown, MD 20545

R. K. Heusser

DP-132, GTN

Office of Nuclear

Materials Production

Germantown, MD 20545
No. of

Copies
F. E. Coffman

DOE Nuclear Waste Management

Programs

NE-50, GTN

Washington, DC 20545

M. L. Lawrence

DOE Nuclear Waste Management Programs

NE-340, GTN

Washington, DC 20545

D. J. McGoff

DOE Nuclear Waste Management Programs

NE-320, GTN

Washington, DC 20545

G. Oertel

DOE Nuclear Waste Management

Programs

NE-320, GTN

Washington, DC 20545

A. F. Perge

DOE Idaho Operations Office

550 2nd Street

Idaho Falls, ID 83401

R. W. Ramsey, Jr.

DOE Nuclear Waste Management Programs

NE-301, GTN

Washington, DC 20545

W. C. Remini

DOE Nuclear Waste Management

Programs

NE-320, GTN

Washington, DC 20545 
No. of

Copies

W. B. Wilson

DOE Savannah River Operations office

P. 0. Box A

Aiken, SC 29801

J. B. Martin

Division of Waste Management Nuclear Regulatory Commission Washington, DC 20555

27 DOE Technical Information Center

J. H. Kittel

Argonne National Laboratory Office of Waste Management

Programs

9700 South Cass Avenue

Argonne, IL 60439

Research Laboratory

Battelle Memorial Institute

505 King Avenue

Columbus, $\mathrm{OH} 43201$

2 R. Williams

Electric Power Research Institute

3412 Hillview Avenue

Palo Alto, CA 94304

Environmental Protection Agency

Technological Assessment Division (AW-559)

Office of Radiation

Programs

Washington, DC 20460

J. R. Berreth

Exxon Nuclear Idaho

P. 0. Box 2800

Idaho Falls, ID 83401
No. of

Copies

G. L. Ritter

Exxon Nuclear Idaho

P. 0. Box 2800

Idaho Falls, ID 83401

J. Campbe 11

Lawrence Livermore Laboratory

P. 0. Box 808

Livermore, CA 94550

W. S. Bennett

Rockwell International

Rocky Flats Plant

P. 0. Box 464

Golden, C0 80401

ONSITE

4 DOE Richland Operations Office

J. J. Schreiber

M. W. Shupe

H. E. Ransom

M. J. Zamorski

4 Rockwell Hanford Operations

J. L. Deichman (2)

W. W. Schulz

R. A. Watrous

Westinghouse Hanford Company

A. G. Blasewitz

57 Pacific Northwest Laboratory

W. J. Bjorklund

W. F. Bonner

T. D. Chikalla

R. D. Dierks

V. F. FitzPatrick

C. R. Hann

A. J. Haverfield 
No. of

Copies

Pacific Northwest Laboratory (Cont.)

P. E. Hart

R. F. Hazelton

J. H. Jarrett

G. A. Jensen (15)

Y. B. Katayama

D. E. Knowlton

J. M. Latkovich

A. W. Lautensleger (10)

R. P. Marshall

J. L. McElroy

G. B. Mellinger

J. E. Minor

R. E. Nightingale

L. D. Perrigo

A. M. Platt

K. H. Rising

F. P. Roberts

G. L. Tingey

H. H. Van Tuyl

E. J. Wheelwright

Technical Information (5)

Publishing Coordination (2) 


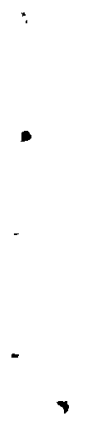

